\title{
Optoelectrical Properties and the Study of Thickness and Annealing in Poly-3-hexylthiophene Based ITO Free Organic Solar Cells with $\mathrm{TiO}_{2}$ and $\mathrm{MoO}_{3}$ as Transport Layers
}

\author{
J. F. Solís-Vivanco ${ }^{a}$, F. De Moure-Flores ${ }^{a}$, S. A. Mayén-Hernández ${ }^{a}$, R. Aruna-Devia
}

\author{
M. L. Gómez-Herrera ${ }^{b}$, J. Santos-Cruz $z^{a *}$ (D)
}

\author{
${ }^{a}$ Universidad Autónoma de Querétaro, Facultad de Química, Materiales-Energía, Querétaro, México. \\ ${ }^{b}$ Universidad Autónoma de Querétaro, Facultad de Ingeniería, Querétaro, México.
}

Received: August 13, 2021; Revised: November 18, 2021; Accepted: December 8, 2021

\begin{abstract}
Inverted organic photovoltaic solar cells were fabricated with the configuration of $\mathrm{FTO} / \mathrm{TiO}_{2} /$ P3HT: $\mathrm{PC}_{61} \mathrm{BM} / \mathrm{MoO}_{3} / \mathrm{Ag}$. Besides, the influence of transport layers, titanium dioxide and molybdenum trioxide, on the performance of solar cells were investigated. These compounds showed excellent optical (around $80 \%$ for molybdenum trioxide and $95 \%$ for titanium dioxide), electrical (like charge carrier density of $3.3 \times 10^{15} \mathrm{~cm}^{-3}$ and $2.5 \times 10^{14} \mathrm{~cm}^{-3}$ for titanium and molybdenum, respectively) and structural (anatase and amorphous hexagonal phase for titanium and molybdenum, respectively) properties to be used as transport layers. Also the influence of the thickness of the electron transport layer is studied, as well as the thickness, temperature and heat treatment time of the active layer. The correct selection of $\mathrm{TiO}_{2}$ 's thickness $(70 \mathrm{~nm})$ and active layer's thickness $(250 \mathrm{~nm})$ and annealing (at 100 degrees for 8 minutes) can increase the power conversion efficiency. Moreover, the cell fabricated with transport layers and the best conditions found showed a maximum efficiency of $3.3 \%$, which indicates that the titanium dioxide and molybdenum trioxide played a determining role in the solar cell performance.
\end{abstract}

Keywords: organic solar cell; transport layer; PCE decay

\section{Introduction}

Over the past few decades, organic photovoltaic solar cells (OPV) have gained the researchers' attention because of their earth-abundant constituents, low cost and easy fabrication process and offers several advantages including light-weight, flexibility, suitability for large-scale production and roll-toroll processing ${ }^{1-4}$. The typical OPV consists of transparent electrodes, active layers, interfacial layers, and metal electrodes. Active layer based on conjugated poly[3-hexylthiophene] (P3HT) polymer donor and [6,6]-phenyl-C61-butyric acid methyl ester (PCBM) fullerene acceptors have widely been investigated due to their excellent optical and electrical properties and have a good stability and lifetime, which is around five years under controlled conditions ${ }^{4-6}$. Besides, interfacial layers such as electron transport layers (ETL) and hole transport layers (HTL) have been incorporated between active layer and electrodes to enhance the power conversion efficiency of the solar cells ${ }^{7,8}$. ETL must be highly transparent to transmit the incident light to the active layer 9 . Furthermore, ETL carries the electrons to the cathode while blocking holes whereas HTL passes the holes to the anode and hampering electrons ${ }^{10}$. Therefore, these transport layers help to extract and collect the photo-generated charge carriers and reduce the recombination, which in turn enhances the performance of solar cells ${ }^{11}$. Moreover, they act as buffer layers that decrease surface imperfections ${ }^{12}$, improves the air stability and lifetime ${ }^{7,13}$.

*e-mail: jsantos@uaq.edu.mx
Poly[3,4-ethylenedioxythiophene]:poly[styrenesulfonate] (PEDOT:PSS) is the most widely used HTL due to its high transparency, hole affinity, and easy solution processability. However, the PEDOT:PSS has several disadvantages such as hygroscopy, humidity, and inhomogeneous electrical properties, which limits the performance of the OPV ${ }^{14}$. In this concern, molybdenum trioxide $\left(\mathrm{MoO}_{3}\right)$ has been used as an HTL due to its energy level alignment, high carrier mobility, and environmental stability. Besides, $\mathrm{MoO}_{3}$ is a polymorph that can be found in three phases: $\alpha-\mathrm{MoO}_{3}$, $\beta-\mathrm{MoO}_{3}$ and $\mathrm{h}-\mathrm{MoO}_{3}{ }^{15}$. On the other hand, titanium dioxide $\left(\mathrm{TiO}_{2}\right)$ is considered to be the most promising ETL in OPV due to its high electron mobility, stability, low cost, and high transparency ${ }^{16}$. It has three phases such as anatase, rutile, and brookite, in which, anatase phase exhibits excellent optical and electrical properties ${ }^{17}$. Herein, the expensive indium tin oxide (ITO) is replaced by fluorine-doped tin oxide (FTO) as a transparent electrode. FTO is less expensive and shows better thermal stability than ITO (over $\left.350^{\circ} \mathrm{C}\right)^{18}$ and it has excellent electrical conductivity, greater mobility and good mechanical stability ${ }^{19}$. In fact, FTO has been recognized as a very promising material for a number of optoelectronic applications $^{18-20}$

Here, the device fabricated with the configuration of FTO/TiO $/ 23 \mathrm{HT}: \mathrm{PC}_{61} \mathrm{BM} / \mathrm{MoO}_{3} / \mathrm{Ag}$ exhibited the highest power conversion efficiency (PCE) of $3.3 \%$. To achieve this efficiency, the study of the optical, electrical and structural properties of the carrier layers was carried out, as well as 
the study of the influence of the thickness of the ETL and the thickness, temperature and annealing time of the active layer. In addition to this, the PCE decay of the constructed cells was studied.

\section{Experimental details}

FTO substrates (Pilkington Tec15) were consecutively cleaned in an ultrasonic bath using soap, acetone, and ethanol for 15 minutes each one. $\mathrm{TiO}_{2}$ sol-gel solution was prepared under the nitrogen atmosphere using titanium (IV) isopropoxide (Sigma-Aldrich, 97\%), ethanol (J.T. Baker, 99.8\%) and hydrofluoric acid (J.T. Baker, 98.51\%). Firstly, $0.117 \mathrm{~mL}$ of hydrofluoric acid was added into $14.2 \mathrm{~mL}$ of ethanol and then $4 \mathrm{~mL}$ of titanium (IV) isopropoxide was added into $14.2 \mathrm{~mL}$ of ethanol in a separate vial. Finally, both the solution was mixed and stirred for 5 minutes to obtain the uniform dispersion. Subsequently, the solution was spin-coated onto the FTO substrate and annealed at $550{ }^{\circ} \mathrm{C}$ for 1 hour in an air atmosphere. Besides, active layer blend was made by dissolving P3HT:PC ${ }_{61} \mathrm{BM}$ (SOL4106 and SOL5061A, respectively, Solaris Chem, 99.5\%) at 1:1 w/w, $25 \mathrm{mg} / \mathrm{mL}$ in o-dichlorobenzene (J. T. Baker, 98.5\%) under the nitrogen atmosphere, and the solution was stirred at $60^{\circ} \mathrm{C}$ for 30 minutes. Then, the blend was deposited over the $\mathrm{TiO}_{2}$ layer by spin coating and annealed for each experiment according to the Table 1 . After that, the $\mathrm{MoO}_{3}$ layer $(\sim 10 \mathrm{~nm})$ was deposited by physical vapor deposition (PVD) using $\mathrm{MoO}_{3}$ powder (Sigma-Aldrich 99.5\%). Finally, silver (Ag) metallic contacts with a thickness of $\sim 100 \mathrm{~nm}$ were deposited by PVD using a mask with a nominal diameter of $1 \mathrm{~mm}$.

The annealing time of active layer was studied by varying time (Experiment $A$ ). In fact, four samples were made for each proposed time ( $5 \mathrm{~s}, 5 \mathrm{~min}, 10 \mathrm{~min}$ and $15 \mathrm{~min}$ ). Samples were named using a three character code: a letter followed by a two-digit number. The letter corresponds to the experiment according to Table 1, the first number corresponds to the time variation, to differentiate between the devices built, and the last one represents the cell. After that the thickness of the ETL and the active layer was studied according to the Experiment $B$. Again, here samples were named using a three character code: the letter corresponds to the experiment according to Table 1, the first number corresponds to the variation of parameters (thicknesses of active layer, and ETL), to differentiate between the devices built, and the last one represents the cells in each device. In this experiment nine devices were made. In Experiment $C$ we use the recommended literature parameters (visible in Table 1) to compare with the cells constructed versus the best parameters found in this research. In this case three different solar cells named $C 1, C 2$ and $C 3$ were fabricated at the same conditions. Finally, using the best ETL's thickness and active layer's thickness and annealing time, found in previous experiments (shown in Table 1), Experiment $D$ was developed and four cells were constructed.

\section{Characterization techniques}

The absorption and transmission spectra of the films were obtained in the range between 300 and $900 \mathrm{~nm}$, using UV-Vis spectrophotometer Genesys S10 Thermoscientific. Raman measurements were carried out using a micro Raman DXR2 Thermoscientific with a blue laser $(455 \mathrm{~nm})$ for $\mathrm{TiO}_{2}$ and $\mathrm{MoO}_{3}$ and a red laser $(633 \mathrm{~nm})$ for the P3HT, $\mathrm{PC}_{61} \mathrm{BM}$, and P3HT:PC ${ }_{61} \mathrm{BM}$ samples. Atomic force microscopy (AFM) images were taken with a dimension of $10 \mu \mathrm{m} \times 10 \mu \mathrm{m}$. X-ray diffraction analysis (XRD) was performed using the Rigaku Ultima IV diffractometer with $\mathrm{Cu} \mathrm{K \alpha}$ radiation $(1.54051 \AA)$ at $40 \mathrm{kV}$ with $15 \mathrm{~mA}$. Finally, Current density-voltage ( $\mathrm{J}-\mathrm{V})$ curves were obtained from the solar simulator model LCS-100 calibrated with AM 1.5 and quantum efficiency measurements were performed using QEPVSi-b, Newport system.

\section{Results and Discussions}

\subsection{Characterization of thin films}

Figure 1 a shows $80 \%$ transmittance in the visible region for $\mathrm{MoO}_{3}$ and $95 \%$ for $\mathrm{TiO}_{2}$ samples. Figure $1 \mathrm{~b}$ depicts the absorption spectra of $\mathrm{P} 3 \mathrm{HT}, \mathrm{PC}_{61} \mathrm{BM}$, and $\mathrm{P} 3 \mathrm{HT}: \mathrm{PC}_{61} \mathrm{BM}$. The observed peak in the range between 350 and $650 \mathrm{~nm}$, ascribed to the $\pi-\pi *$ electronic transition of $\mathrm{P} 3 \mathrm{HT}$ polymer and the $\mathrm{PC}_{61} \mathrm{BM}$ exhibits absorption in the range between 300 and $400 \mathrm{~nm}$, while P3HT:PC ${ }_{61} \mathrm{BM}$ blend shows the absorption at 300 and $650 \mathrm{~nm}$. The bandgap of $1.9 \mathrm{eV}$ and $2 \mathrm{eV}$, corresponding to the $\mathrm{P} 3 \mathrm{HT}$ and $\mathrm{PC}_{61} \mathrm{BM}$ polymers, respectively, according with the literature ${ }^{21}$. Then, the bandgap was calculated for both $\mathrm{TiO}_{2}$ and $\mathrm{MoO}_{3}$ using the Tauc plot, which is found to be $3.2 \mathrm{eV}$ and $3.6 \mathrm{eV}$, respectively, for this experiment, and can be seen in Figure 2.

Raman spectra of $\mathrm{TiO}_{2}$ and $\mathrm{MoO}_{3}$ films are shown in Figure 3. The $\mathrm{TiO}_{2}$ sample showed vibrational modes at $138 \mathrm{~cm}^{-1}$, $191 \mathrm{~cm}^{-1}, 392 \mathrm{~cm}^{-1}, 509 \mathrm{~cm}^{-1}$ and $632 \mathrm{~cm}^{-1}$, attributed to Ti-O bond ${ }^{22}$. The $\mathrm{MoO}_{3}$ film showed the characteristic modes at $242 \mathrm{~cm}^{-1}, 283 \mathrm{~cm}^{-1}, 336 \mathrm{~cm}^{-1}, 373 \mathrm{~cm}^{-1}, 664 \mathrm{~cm}^{-1}, 815 \mathrm{~cm}^{-1}$, $958 \mathrm{~cm}^{-1}$ and $991 \mathrm{~cm}^{-1}$, ascribed to binding and stretching modes of $\mathrm{Mo}-\mathrm{O}_{3}$. Besides, the peak obtained at $552 \mathrm{~cm}^{-1}$ and $1090 \mathrm{~cm}^{-1}$, corresponding to the glass substrates ${ }^{23}$. Furthermore, P3HT:PC ${ }_{61}$ BM blend exhibited peak at $731 \mathrm{~cm}^{-1}, 1386 \mathrm{~cm}^{-1}$, $1449 \mathrm{~cm}^{-1}, 1469 \mathrm{~cm}^{-1}$ and $2889 \mathrm{~cm}^{-124,25}$. The observed vibrational mode at $731 \mathrm{~cm}^{-1}$ corresponds to the vibrational deformation of the C-S-C molecular bond ${ }^{24}$, and peak at

Table 1. Variation of parameters in experiments with the configuration $\mathrm{FTO} / \mathrm{TiO}_{2} / \mathrm{P} 3 \mathrm{HT}: \mathrm{PC}_{61} \mathrm{BM} / \mathrm{MoO}_{3} / \mathrm{Ag}$

\begin{tabular}{cccc}
\hline Experiment & $\mathrm{TiO}_{2}$ layer $(\mathrm{nm})$ & Active layer $(\mathrm{nm})$ & $\begin{array}{c}\text { Active layer's annealing } \\
\text { time }\end{array}$ \\
\hline $\mathrm{A}$ & 70 & 200 & $5 \mathrm{~s} ; 5,10$ and $15 \mathrm{~min}$ \\
\hline $\mathrm{B}$ & $40,55,70$ & $150,200,250$ & $10 \mathrm{~min}$ \\
\hline $\mathrm{C}$ & 70 & 180 & $15 \mathrm{~min}$ \\
\hline $\mathrm{D}$ & 70 & 250 & $8 \mathrm{~min}$ \\
\hline
\end{tabular}



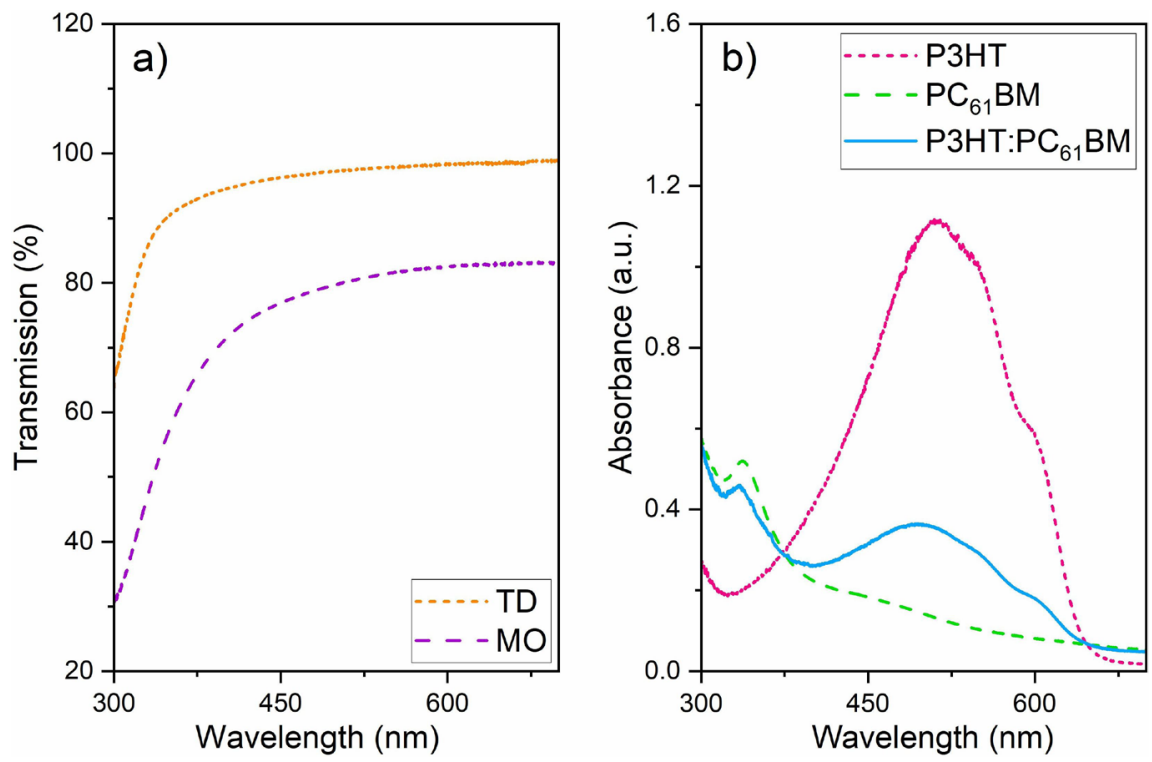

Figure 1. a) Transmission spectra of $\mathrm{TiO}_{2}(\mathrm{TD})$ and $\mathrm{MoO}_{3}(\mathrm{MO})$ thin films and $\mathrm{b}$ ) absorption spectra of $\mathrm{P} 3 \mathrm{HT}, \mathrm{PC}_{61} \mathrm{BM}$ and $\mathrm{P} 3 \mathrm{HT}: \mathrm{PC}_{61} \mathrm{BM}$ films annealed at $120^{\circ} \mathrm{C}$.
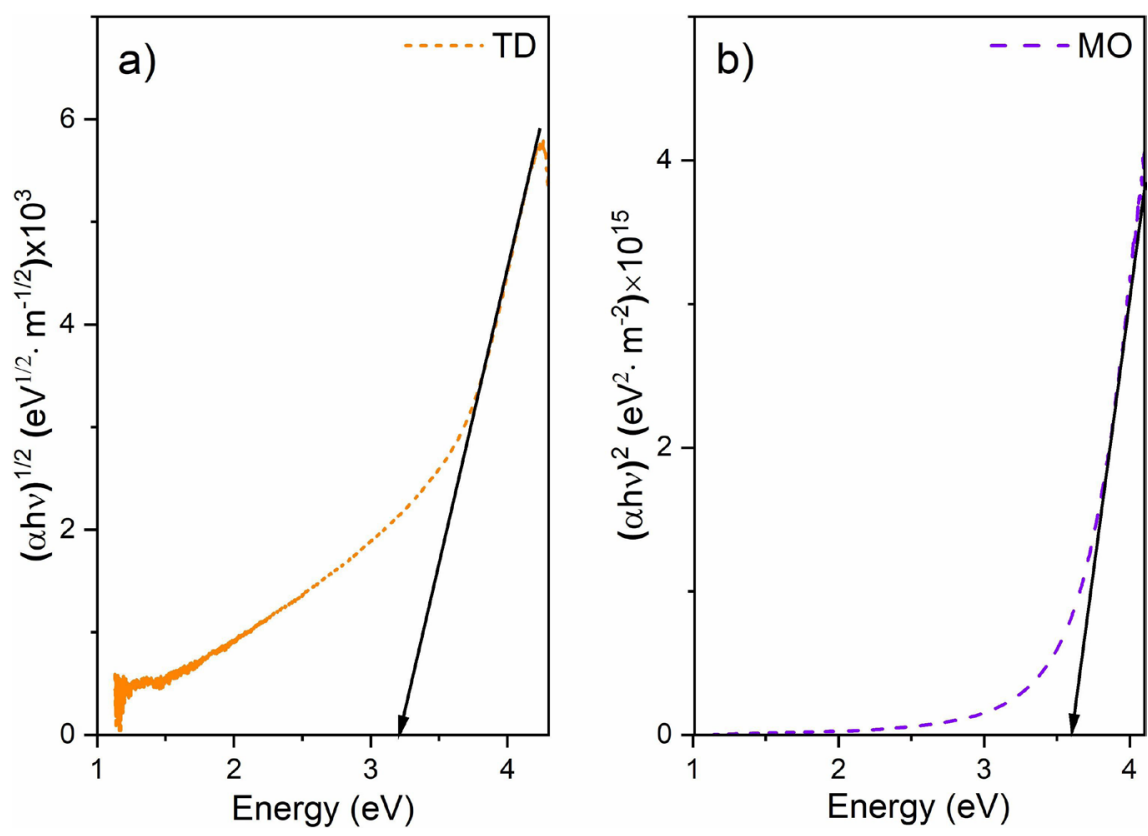

Figure 2. Tauc plots of a) $\mathrm{TiO}_{2}(\mathrm{TD})$ and b) $\mathrm{MoO}_{3}(\mathrm{MO})$.

$1386 \mathrm{~cm}^{-1}$ represents the $\mathrm{C}-\mathrm{C}$ bond of the main structure ${ }^{25}$. Also, vibrational modes at $1449 \mathrm{~cm}^{-1}$ and $1469 \mathrm{~cm}^{-1}$ are related to the $\mathrm{C}=\mathrm{C}$ bond in aggregate and non-aggregated chains of P3HT thiophene ring ${ }^{24-26}$. Finally, the observed vibrational mode at $2889 \mathrm{~cm}^{-1}$ corresponds to the $\mathrm{C}-\mathrm{H}$ bond ${ }^{25}$.

XRD patterns of $\mathrm{TiO}_{2}$ and $\mathrm{MoO}_{3}$ samples are shown in Figure 4. The observed diffraction planes of (101), (004), (200), (105), (204), (116) and (115) attributed to the anatase phase of $\mathrm{TiO}_{2}(\mathrm{JCPDS} 21-1272)^{27}$. Moreover, $\mathrm{MoO}_{3}$ thin film showed (210), (300), (220), (310), (320), (410), (008), (218), (424) and (524) planes, which correspond to the amorphous hexagonal phase: $h-\mathrm{MoO}_{3}(\mathrm{JCPDS} 21-0569)^{28,29}$.
Figure 5 shows the 2D and 3D AFM images of TiO and $\mathrm{MoO}_{3}$ films with dimensions of $10 \mu \mathrm{m} \times 10 \mu \mathrm{m}$. For $\mathrm{TiO}_{2}$, the obtained average roughness $(\mathrm{Ra})$ and the mean square roughness (Rms) values of $\sim 1.36 \mathrm{~nm}$ and $\sim 1.74 \mathrm{~nm}$ are relatively low, which reveals the uniformity and surface homogeneity of the film ${ }^{30}$. Hence, the results suggested that the $\mathrm{TiO}_{2}$ surface is favorable for the active layer deposition ${ }^{31}$. Moreover, the $\mathrm{Ra}$ and $\mathrm{Rms}$ values of $\mathrm{MoO}_{3}$ were found to be $\sim 1.59 \mathrm{~nm}$ and $\sim 2.31 \mathrm{~nm}$, respectively, indicating the uniform distribution obtained from the physical vapor deposition ${ }^{31}$. According to Figure $5 \mathrm{a}, \mathrm{TiO}_{2}$ sample are turned out to be strongly polydispersive with particles, which have a nearly 


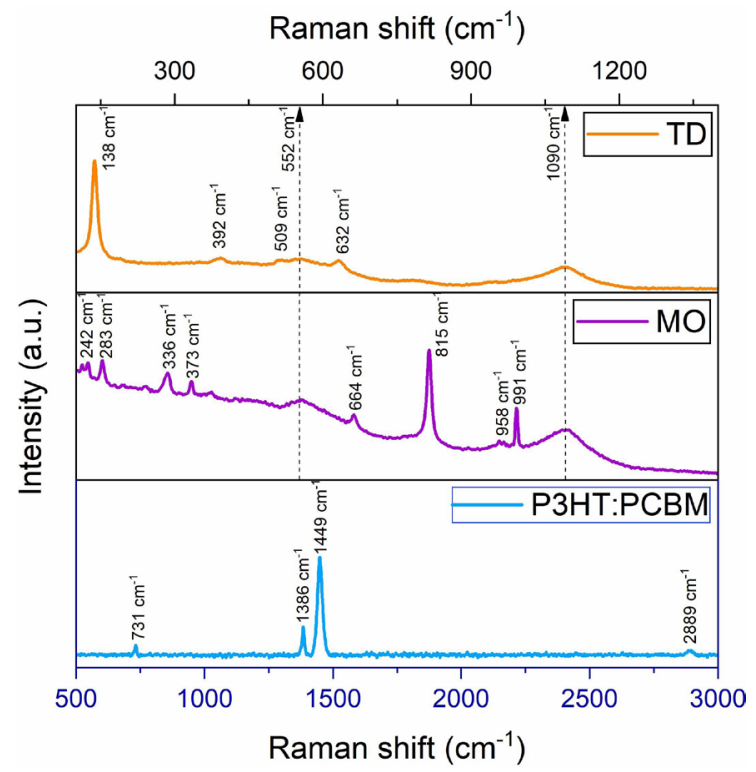

Figure 3. Raman spectra of $\mathrm{TiO}_{2}(\mathrm{TD}), \mathrm{MoO}_{3}(\mathrm{MO})$ and $\mathrm{P} 3 \mathrm{HT}: \mathrm{PC}_{61} \mathrm{BM}$ thin films.

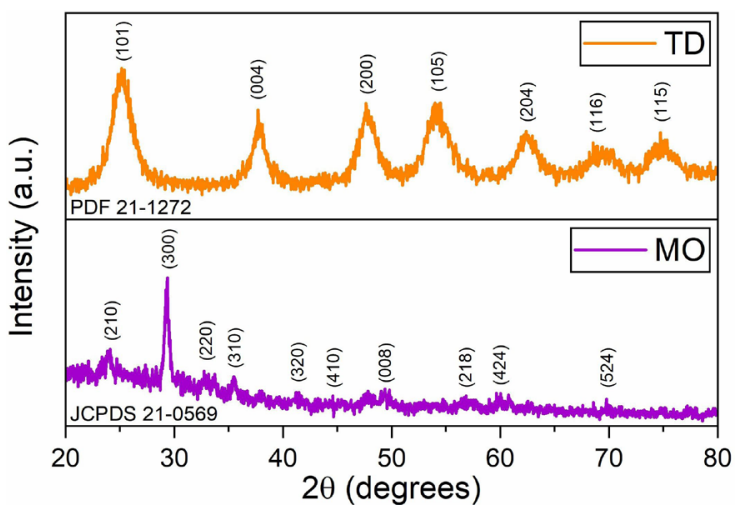

Figure 4. XRD patterns of $\mathrm{TiO}_{2}$ (TD)annealed at $550{ }^{\circ} \mathrm{C}$ and amorphous hexagonal phase of $\mathrm{MoO}_{3}(\mathrm{MO})$ thin films. spherical shape and consists of many nanocrystallites that grown together and combined into larger agglomerates forming structures up to $18 \mathrm{~nm}$ in size ${ }^{32}$. The surface morphological image of the $\mathrm{MoO}_{3}$ sample (Figure 5b, supports the amorphous nature of the film and it's possible to see needle-like morphology and nanosized grains which are fused compactly together ${ }^{33}$.

From the Hall-effect measurements, the observed charge carrier density of $3.3 \times 10^{15} \mathrm{~cm}^{-3}$ and resistivity of $4.0 \times 10^{4} \Omega \cdot \mathrm{cm}$, corresponding to the $\mathrm{TiO}_{2}$ films. For $\mathrm{MoO}_{3}$ films, the charge carrier density of $2.5 \times 10^{14} \mathrm{~cm}^{-3}$, mobility of $4.6 \mathrm{~cm}^{2} / \mathrm{V} \cdot \mathrm{s}$ and resistivity of $1.46 \times 10^{4} \Omega \cdot \mathrm{cm}$ values were observed. The combination of ETL and HTL improves the transport carrier (electrons to cathode and holes to anode) minimizing recombination of charge carriers and increasing the fill factor $(\mathrm{FF})^{34}$.

\subsection{Solar devices}

Figure 6 a depicts the inverted solar cell structure of FTO/TiO $/ 23 \mathrm{HT}: \mathrm{PC}_{61} \mathrm{BM} / \mathrm{MoO}_{3} / \mathrm{Ag}$, in which, FTO works as a cathode and $\mathrm{Ag}$ works as an anode. Herein, photons travel to the active layer through the cathode and the ETL. The inverted structure offers several advantages including better photon harvest, the possibility of high-temperature annealing for ETL layer $\left(550{ }^{\circ} \mathrm{C}\right.$ to reach anatase phase), due to the FTO's high thermal stability in contrast to the maximum temperature of ITO, which is $350^{\circ} \mathrm{C}$.

Figure $6 \mathrm{~b}$ shows a schematic representation of the energy level diagram. The energy level offset, reported in literature and shown, between the donor ( $\mathrm{P} 3 \mathrm{HT})$ and acceptor $\left(\mathrm{PC}_{61} \mathrm{BM}\right)$ interface is $0.6 \mathrm{eV}^{35}$. Besides, the reported conduction band value $(-4.2) \mathrm{eV}$ of $\mathrm{TiO}_{2}$ is close to the work function of FTO $(-4.4 \mathrm{eV})$, indicating ohmic contact which in turn facilitates the electron transfer ${ }^{36}$. Similarly, the work function $(-5.3 \mathrm{eV})$ of $\mathrm{MoO}_{3}$ leads to ohmic contact with the donor polymer that transports holes to the $\mathrm{Ag}$ (anode).

\subsubsection{Experiment A: Variation of annealing time.}

The results can be consulted in the Table 2 and the Figure 7. As it is possible to observe, Table 2 shows the best sample (of the four samples made) for each proposed
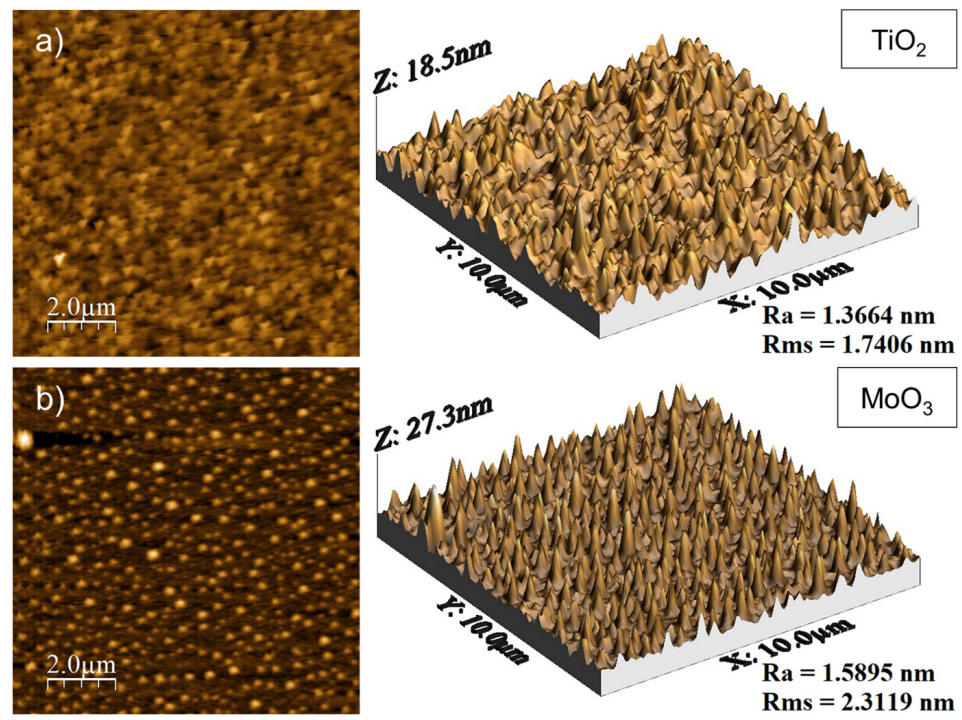

Figure 5. AFM images of a) $\mathrm{TiO}_{2}$ and b) $\mathrm{MoO}_{3}$ thin films. 
a)

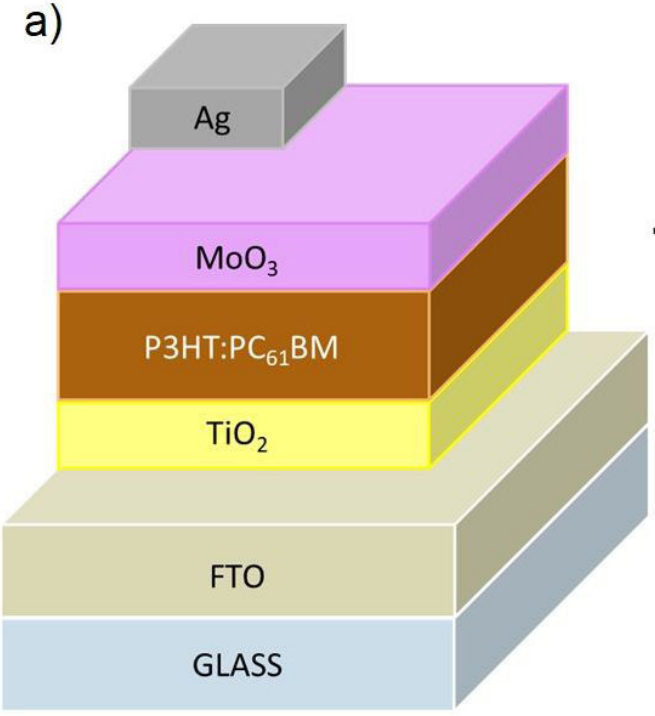

b)

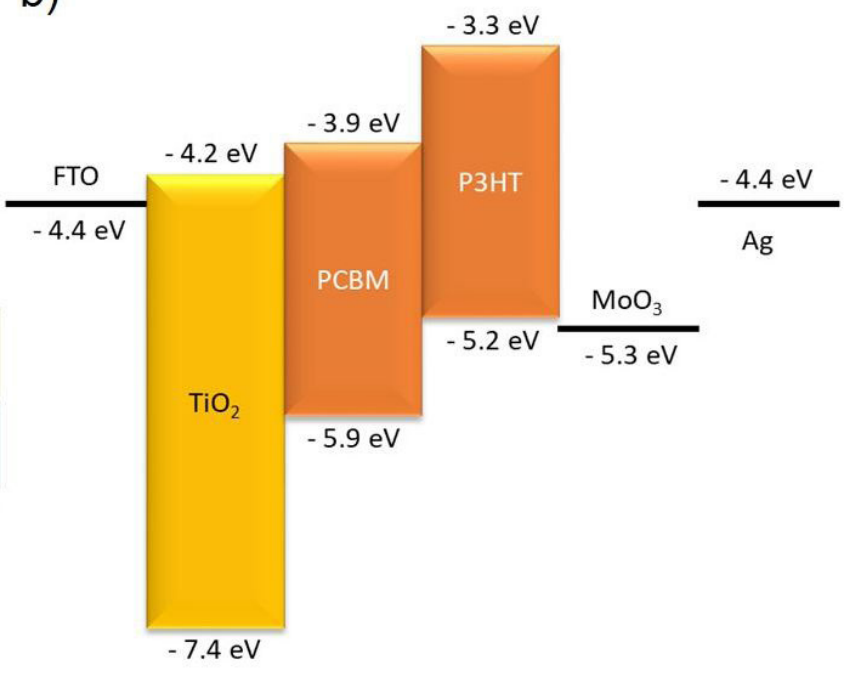

Figure 6. (a) Device structure and (b) energy level diagram of the fabricated OPV.

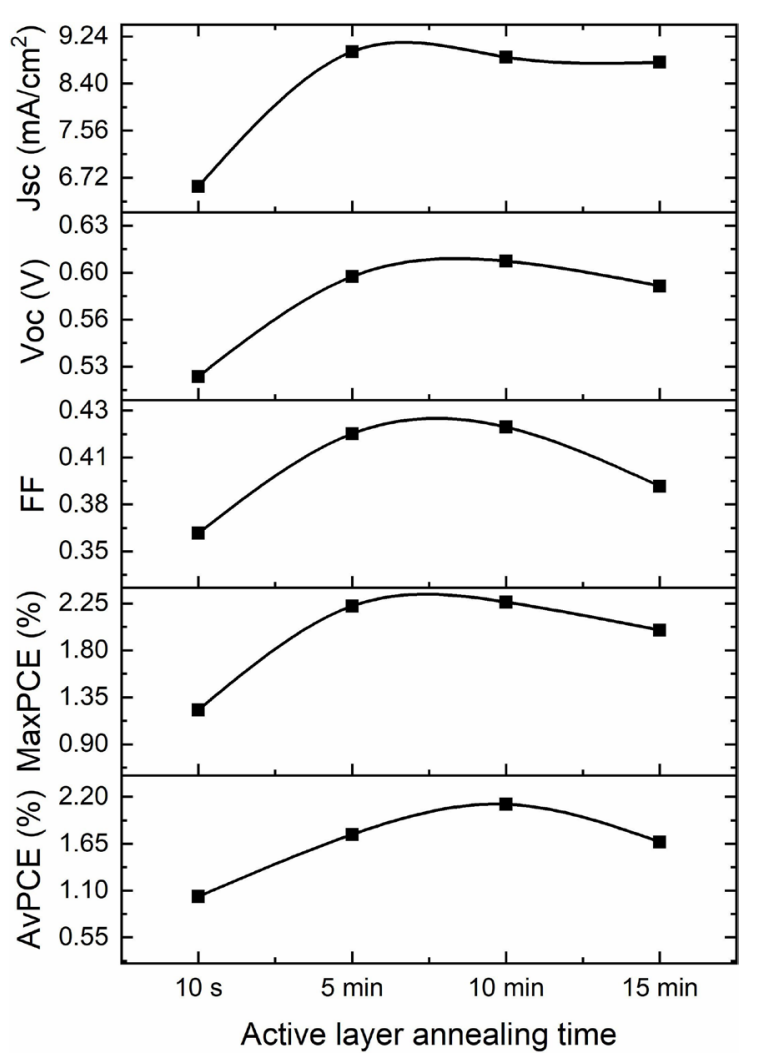

Figure 7. Parameters and tendence line of the annealing time's variation in cells according to the Experiment A.

time ( $5 \mathrm{~s}, 5 \mathrm{~min}, 10 \mathrm{~min}$ and $15 \mathrm{~min}$ ). Also, short-circuit current density (Jsc), open-circuit voltage (Voc), fill factor (FF), power conversion efficiency (PCE) and the average PCE (Av. PCE) were shown. The same parameters, of the best cell of each device and the average of the device, are shown in the Figure 6, where the trend line is also observed.
A minimum time of $10 \mathrm{~s}$ was used because it is quite close to not having used heat treatment, but necessary to promote the relative crystallinity of the polymers and possibly eliminate residual solvent. Just in this time PCE and Av. PCE were the worst showed in the Table 2, with a maximum PCE of $1.23 \%$ (cell A11) and an average PCE of $1.03 \%$. By increasing the treatment time, it is observed that PCE and Av. PCE also increase until 10 min of annealing is reached. Here (10 min of annealing), a minimum PCE of $1.84 \%$, a maximum of $2.26 \%$ and an average PCE of $2.11 \%$ were observed. It is possible to say that by increasing the treatment time a greater amount of residual solvent is eliminated and the relative crystallinity of the polymers of the active layer is improved. However, apparently, by continuing to increase the heat treatment time (greater than 10 minutes), it is observed that the PCE begins to decrease. This is seen in the maximum PCE $(2 \%)$ of the cells treated for $15 \mathrm{~min}$, as well as in their average (1.67\%). This could be related to the breaking of the polymer chains of the active layer. In general, the trend found is not only observed in the PCE, since it can also be seen in the Jsc, the Voc and the FF. Considering only the results of the best cell of each device, it can be seen that the PCE, the FF, the Voc and the Jsc are quite close in the devices annealed for 5 minutes and for 10 minutes. One could venture to say that a better time could exist between 5 and 10 minutes, but close to the latter.

\subsubsection{Experiment B: Variation of active layer and ETL thicknesses.}

The results of Experiment $B$ can be consulted in the Table 3 and the Figure 8. Also, Jsc, Voc, FF, PCE and Av. PCE were shown. For this experiment, the best cell of each device and the average of the device were graphed and they are shown in the Figure 7, where the trend line is observed, too.

The Table 3 shows that the best PCE (2.5\%) and average PCE (2.27\%)correspond to the device with the greatest thicknesses used for the active layer (AL) and ETL: $70 \mathrm{~nm}$ 
Table 2. Experiment $\mathrm{A}$ and the variation of their parameters in cells with the configuration $\mathrm{FTO} / \mathrm{TiO}_{2} / \mathrm{P} 3 \mathrm{HT}: \mathrm{PC}_{61} \mathrm{BM} / \mathrm{MoO}_{3} / \mathrm{Ag}$

\begin{tabular}{ccccccc}
\hline Time & Sample & Jsc $\left(\mathrm{mA} / \mathrm{cm}^{2}\right)$ & Voc (Volts) & $F F$ & Max. PCE (\%) & Av. PCE (\%) \\
\hline $10 \mathrm{~s}$ & A11 & 6.56 & 0.52 & 0.36 & 1.23 & 1.03 \\
\hline $5 \mathrm{~min}$ & A22 & 8.97 & 0.59 & 0.42 & 2.22 & 1.76 \\
\hline $10 \mathrm{~min}$ & A34 & 8.87 & 0.60 & 0.42 & 2.26 & 2.11 \\
\hline $15 \mathrm{~min}$ & A44 & 8.78 & 0.59 & 0.39 & 2.00 & 1.67 \\
\hline
\end{tabular}

Table 3. Experiment $\mathrm{B}$ and the variation of their parameters in cells with the configuration $\mathrm{FTO} / \mathrm{TiO}_{2} / \mathrm{P} 3 \mathrm{HT}: \mathrm{PC}_{61} \mathrm{BM} / \mathrm{MoO}_{3} / \mathrm{Ag}$

\begin{tabular}{|c|c|c|c|c|c|c|c|}
\hline $\mathrm{TiO}_{2}(\mathrm{~nm})$ & $A L(\mathrm{~nm})$ & Sample & $J_{s c}\left(\mathrm{~mA} / \mathrm{cm}^{2}\right)$ & Voc (Volts) & $F F$ & Max. PCE (\%) & $A v \cdot P C E(\%)$ \\
\hline \multirow[t]{3}{*}{70} & 250 & $\mathrm{~B} 12$ & 9.75 & 0.63 & 0.41 & 2.50 & 2.27 \\
\hline & 200 & $\mathrm{~B} 23$ & 8.54 & 0.58 & 0.33 & 1.64 & 1.50 \\
\hline & 150 & B32 & 7.91 & 0.53 & 0.33 & 1.40 & 1.21 \\
\hline \multirow[t]{3}{*}{55} & 250 & B41 & 8.87 & 0.52 & 0.35 & 1.61 & 1.25 \\
\hline & 200 & B52 & 7.33 & 0.46 & 0.29 & 0.97 & 0.55 \\
\hline & 150 & B65 & 6.54 & 0.43 & 0.31 & 0.87 & 0.56 \\
\hline \multirow[t]{3}{*}{40} & 250 & B75 & 7.09 & 0.48 & 0.27 & 0.91 & 0.77 \\
\hline & 200 & B84 & 6.04 & 0.38 & 0.26 & 0.59 & 0.35 \\
\hline & 150 & B94 & 7.58 & 0.47 & 0.35 & 1.23 & 0.97 \\
\hline
\end{tabular}

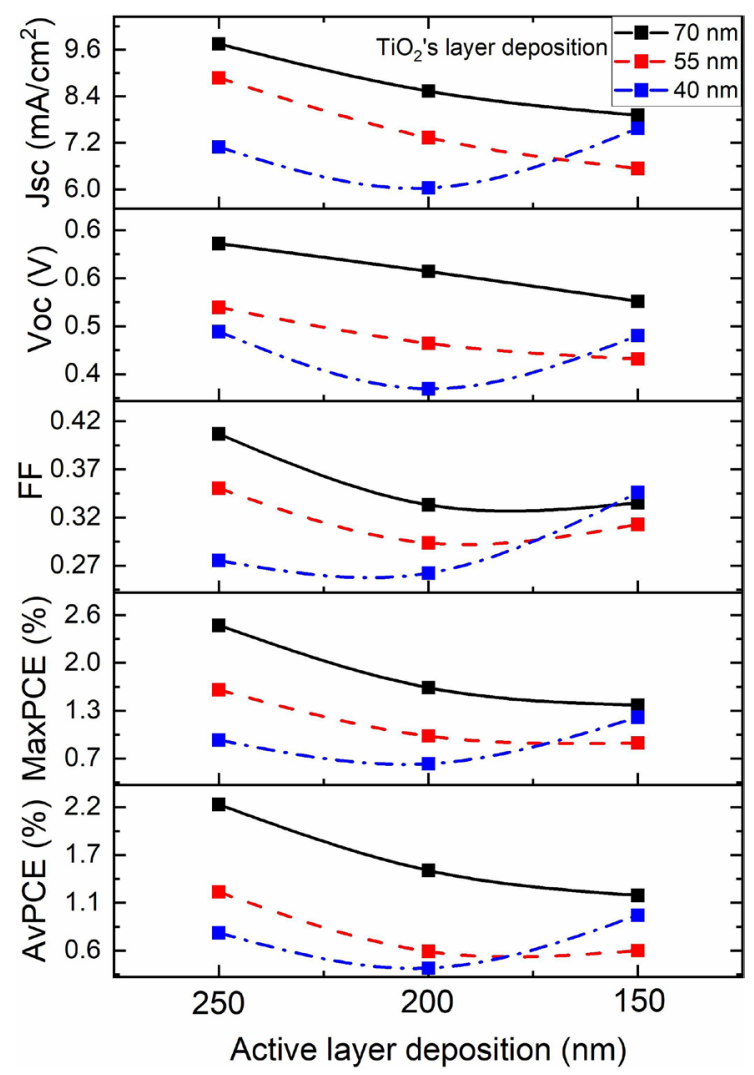

Figure 8. Parameters and tendence line of the thicknesses variation in cells according to the Experiment B.

and $250 \mathrm{~nm}$, for ETL and active layer, respectively. On the other hand, the worst device constructed corresponds to the device with an ETL thickness of $40 \mathrm{~nm}$ and an active layer of $200 \mathrm{~nm}$, which correspond to an average PCE of $0.35 \%$. In fact, in this experiment, the best cell constructed corresponds to the cell $B 12$, which has a Jsc of $9.75 \mathrm{~mA} / \mathrm{cm}^{2}$, a Voc of 0.63 Volts, a FF of 0.41 , a PCE of $2.5 \%$, while the worst cell showed corresponds to the cell $B 84$, which has a Jsc of $6.04 \mathrm{~mA} / \mathrm{cm}^{2}$, a Voc of 0.38 , a FF of 0.26 and a PCE of $0.35 \%$.

Using Figure 8, it is possible to observe the tendence lines in this experiment. In general, it is shown how the PCE increases with increasing thickness of the films under study and this applies to both the active layer and the ETL. Larger active layer thicknesses increase the number of photogenerated electron-hole pairs, increasing in turn the Voc and Jsc of the constructed cells, which in turn benefits the FF and therefore the PCE, maximum and average. Meanwhile, increasing the thickness of the ETL also increases the Jsc, the Voc, the FF and therefore the PCE, this is due to the fact that the distance traveled by the electrons in this layer increases, increasing the volume of charge carriers that can be displaced and decreasing the probability of recombination of the charge carriers. Both observations can be stated with certainty for the trend lines with the ETL of 70 and $55 \mathrm{~nm}$. However, this trend is not completely fulfilled in the trend line corresponding to a $40 \mathrm{~nm}$ ETL, this due to the fact that there is an outlier in the device with a $150 \mathrm{~nm}$ active layer, departing from the observed trend.

In addition, it is necessary to say that only the ETL was varied and not the HTL, because the work function of the $\mathrm{MoO}_{3}$ is slightly lower $(-5.3 \mathrm{eV})$ than the HOMO of the P3HT $(-5.2 \mathrm{eV})$ and to increase the thickness of this layer would increase the probability of recombination of the charge carriers. On the other hand, using PVD system it is not possible to deposit a lower thickness of $\mathrm{MoO}_{3}$ without affecting the homogeneity of the layer.

\subsubsection{Experiment $C$ : Application of literature parameters}

Figure 9 depicts the J-V curves of the fabricated OPV and Table 4 shows the device parameters of Jsc, Voc, FF, PCE and Av. PCE values. The Jsc was changed from 10.97 to 11.23 and slight changes were observed in FF and Voc values, 
Table 4. Solar cell device properties of the device fabricated in the Experiment $\mathrm{C}$ with the configuration of $\mathrm{FTO} / \mathrm{TiO} / \mathrm{P} 3 \mathrm{HT}: \mathrm{PC}{ }_{61} \mathrm{BM} /$ $\mathrm{MoO}_{3} / \mathrm{Ag}$

\begin{tabular}{|c|c|c|c|c|c|}
\hline Sample & $J_{S c}\left(m A / \mathrm{cm}^{2}\right)$ & Voc (Volts) & Fill Factor & $P C E(\%)$ & PCE average (\%) \\
\hline$C 1$ & 11.17 & 0.61 & 0.45 & 3.12 & 3.07 \\
\hline$C 2$ & 10.97 & 0.61 & 0.45 & 3.03 & \\
\hline C3 & 11.23 & 0.60 & 0.45 & 3.05 & \\
\hline
\end{tabular}

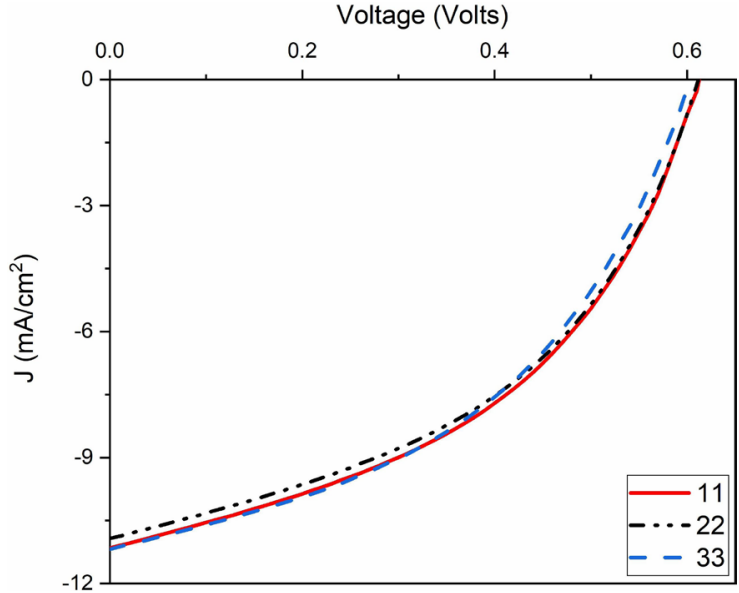

Figure 9. J-V curves of the device fabricated in the Experiment $\mathrm{C}$ with the configuration of $\mathrm{FTO} / \mathrm{TiO}_{2} / \mathrm{P} 3 \mathrm{HT}: \mathrm{PC}_{61} \mathrm{BM} / \mathrm{MoO}_{3} / \mathrm{Ag}$.

as can be seen in Table 4. Moreover, the device efficiency was varied from 3.03 to $3.12 \%$ and the average PCE was found to be $3.07 \%$. Therefore, the observed differences in the PCE were relatively low, which revealed the high reproducibility of the fabricated OPV in this work. Also, the FF was low in comparison with other organic solar cells. This low FF is attributed to shunt resistance $\left(\mathrm{R}_{\mathrm{SH}}\right)$ and series resistance $\left(\mathrm{R}_{\mathrm{S}}\right)$. $\mathrm{R}_{\mathrm{SH}}$ is caused by manufacturing or natural intrinsic defects and includes leakage of current in the layers, in the limits of the cell, by difference of energy levels that act as "traps" or by recombination of charge carriers. Meanwhile, resistance in the active layer, the resistance provided by the electrodes and the resistance caused by the contact of the interfaces in the device contribute to $\mathrm{R}_{\mathrm{S}}{ }^{37}$. To achieve a good interface's contact the device is usually annealing after fabrication to $110{ }^{\circ} \mathrm{C}$ for 10 minutes $^{38}$. For this work, no annealing was made, because there's no shown an improvement in the interface contact and that decreased the FF and PCE.

External quantum efficiency (EQE) curves of the device are shown in Figure 10. The measured EQE was about $23 \%$ and the observed changes in the EQE are directly proportional to the PCE of the device. Furthermore, EQE exhibits photocurrent in the wavelength ranging from 300 to $650 \mathrm{~nm}$, which is consistent with the UV-Vis absorption of the P3HT:PC ${ }_{61} \mathrm{BM}$ blend (Figure 1b).

Figure 11 shows the cross-sectional SEM of the cells, C1, $C 2$ and $C 3$, presented in this work. In Figure 11a the SEM image corresponding to cell $C 1$ shows FTO, the polymer blend and $\mathrm{MoO}_{3} / \mathrm{Ag}$. In that cell is not possible to see the $\mathrm{TiO}_{2}$ and also the blend has a tear, possibly caused during sample preparation, which covers $\mathrm{MoO}_{3}$ and $\mathrm{Ag}$ layers. Figure $11 \mathrm{~b}$ shows the $\mathrm{FTO} / \mathrm{TiO}_{2}$ layers and polymers layer

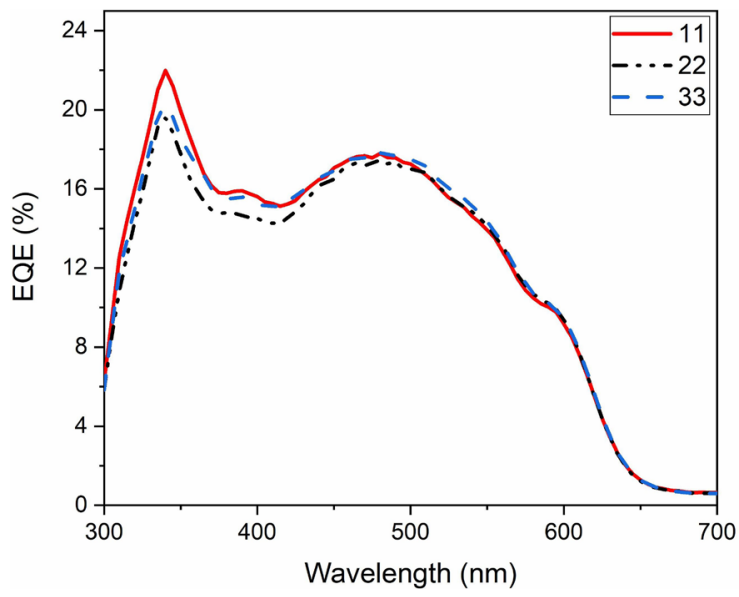

Figure 10. External quantum efficiency of the device fabricated with the configuration of $\mathrm{FTO} / \mathrm{TiO}_{2} / \mathrm{P} 3 \mathrm{HT}: \mathrm{PC}_{61} \mathrm{BM} / \mathrm{MoO}_{3} / \mathrm{Ag}$.

corresponding to cell $C 2$. Finally, Figure 11c shows FTO, $\mathrm{TiO}_{2}$, polymers blend and the $\mathrm{MoO}_{3} / \mathrm{Ag}$ layers corresponding to cell $C 3$. Using these SEM images, the estimated thickness mentioned in "experimental details" were verified.

\subsubsection{Experiment D: Enhanced devices with the best found parameters.}

The results of the Experiment $D$ were shown in Table 5 and Figure 12. It's possible to see that the best cell corresponds to the cell D4, which has a Jsc of $12.49 \mathrm{~mA} / \mathrm{cm}^{2}$, a Voc of 0.55 Volts, a FF of 0.48 and a PCE of $3.3 \%$. On the other hand, the worst cell was the cell $D 1$, which exhibits a Jsc of $11.79 \mathrm{~mA} / \mathrm{cm}^{2}$, a Voc of 0.53 Volts, a FF of 0.5 (the best value found in this research) and a PCE of $3.15 \%$. The average PCE was $3.21 \%$. It is easy to show that by using the best cell construction parameters, which were high ETL and active layer thicknesses, treatment time equal to or slightly less than $10 \mathrm{~min}$, as well as measuring the cells on the same day, an increase in the electrical properties of the constructed cells is obtained. In comparison with Experiment $C$, in Experiment $D$ it is observed that by decreasing the treatment time and temperature, which leads to a substantial decrease in Voc, but consequently, Jsc and FF increase helping the relative increase of PCE.

Furthermore, the obtained device parameters were compared with the literature values as can be seen in Table 6 . The efficiency decreased by $1.85 \%$ when they incorporated layers of $\mathrm{MoO}_{3}$ and $\mathrm{TiO}_{2}$ to the device, compared to the base cell with PEDOT-PSS Here, it is worth to mention that the maximum PCE of $3.3 \%$ was achieved using HTL and ETL and the best conditions in this work. Moreover, the device was fabricated with and without HTL and ETL. The device 
Table 5. Solar cell device properties of the device fabricated in the Experiment $\mathrm{D}$ with the configuration of $\mathrm{FTO} / \mathrm{TiO}_{2} / \mathrm{P} 3 \mathrm{HT}: \mathrm{PC}{ }_{61} \mathrm{BM} /$ $\mathrm{MoO}_{3} / \mathrm{Ag}$

\begin{tabular}{cccccc}
\hline Sample & $J_{S C}\left(\mathrm{~mA} / \mathrm{cm}^{2}\right)$ & Voc (Volts) & $F F$ & $P C E(\%)$ & Av. PCE (\%) \\
\hline D1 & 11.79 & 0.53 & 0.50 & 3.15 & 3.21 \\
D2 & 12.43 & 0.52 & 0.49 & 3.17 & \\
D3 & 12.20 & 0.55 & 0.48 & 3.23 \\
\hline D4 & 12.49 & 0.55 & 0.48 & 3.30 \\
\hline
\end{tabular}

Table 6. Comparison of electrical properties of fabricated OPV with the literature

\begin{tabular}{ccccccccc}
\hline Sample & Anode & $H T L$ & $E T L$ & Cathode & $J_{S c}\left(\mathrm{~mA} / \mathrm{cm}^{2}\right)$ & Voc (Volts) & FF & $P C E(\%)$ \\
\hline$P W$ & $\mathrm{Ag}$ & - & - & FTO & 6.66 & 0.22 & 0.30 & 0.44 \\
\hline $11 P W$ & $\mathrm{Ag}$ & $\mathrm{MoO}_{3}$ & $\mathrm{TiO}_{2}$ & FTO & 12.49 & 0.55 & 0.48 & 3.30 \\
\hline $\operatorname{Ref}\left[{ }^{39}\right]$ & $\mathrm{ITO}$ & PEDOT:PSS & - & $\mathrm{Al}$ & 12.80 & 0.64 & 0.63 & 5.15 \\
\hline $\operatorname{Ref}\left[{ }^{40}\right]$ & $\mathrm{ITO}$ & $\mathrm{MoO}_{3}$ & - & $\mathrm{LiF} / \mathrm{Al}$ & 4.99 & 0.61 & 0.41 & 1.25 \\
\hline $\operatorname{Ref}\left[{ }^{41}\right]$ & $\mathrm{Ag}$ & $\mathrm{MoO}_{3}$ & $\mathrm{TiO}_{x}$ & ITO & 7.94 & 0.52 & 0.44 & 1.81 \\
\hline
\end{tabular}
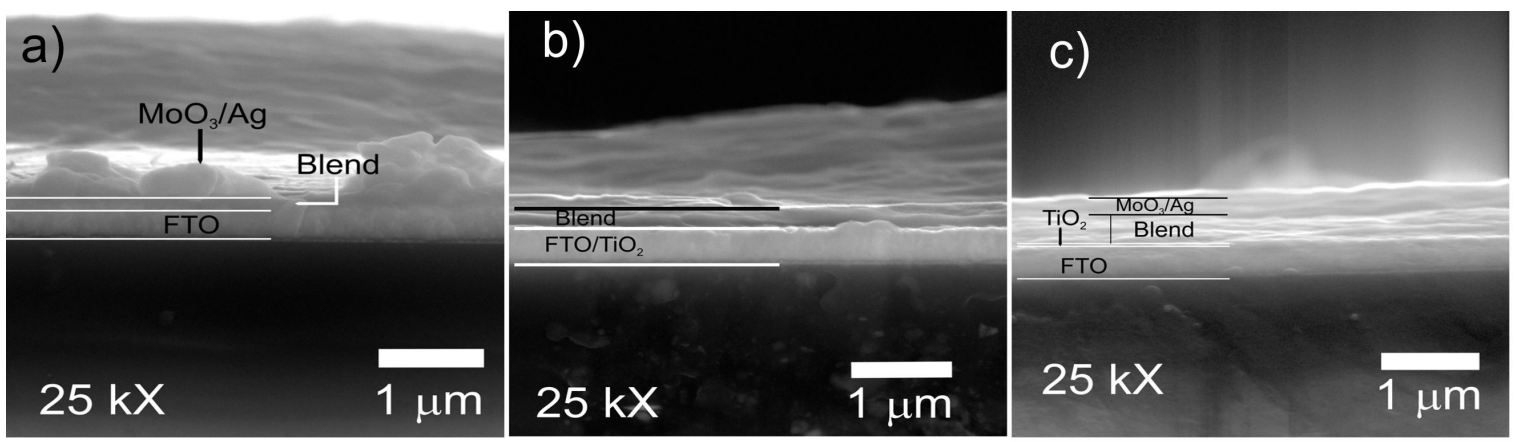

Figure 11. Cross-sectional SEM of the cells a) $\mathrm{C} 1$, b) $\mathrm{C} 2$ and c) $\mathrm{C} 3$ with the configuration $\mathrm{FTO} / \mathrm{TiO}_{2} / \mathrm{P}_{3} \mathrm{HT}_{\mathrm{PC}} \mathrm{PC}_{61} \mathrm{BM} / \mathrm{MoO} / \mathrm{Ag}$.

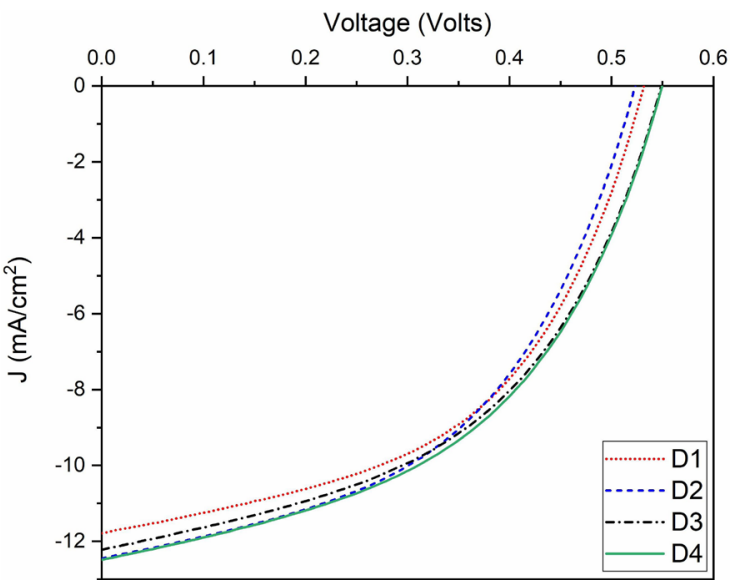

Figure 12. $\mathrm{J}-\mathrm{V}$ curves of the device fabricated in the Experiment $\mathrm{D}$ with the configuration of $\mathrm{FTO} / \mathrm{TiO}_{2} / \mathrm{P} 3 \mathrm{HT}: \mathrm{PC}_{61} \mathrm{BM} / \mathrm{MoO}_{3} / \mathrm{Ag}$.

parameters such as Jsc, Voc, and FF values were significantly improved with HTL and ETL. Therefore, the efficiency was greatly increased from $0.44 \%$ to $3.3 \%$ as can be seen in Table 6. These results suggested that the HTL and ETL play a crucial role in the performance of the OPV as mentioned earlier. Nevertheless, the highest efficiency of 5\% reported in the literature ${ }^{39}$ was obtained with the device configuration of ITO/PEDOT:PSS/P3HT:PC ${ }_{61} \mathrm{BM} / \mathrm{Al}$ (or $\mathrm{LiF} / \mathrm{Al}$ or $\mathrm{Ca} / \mathrm{Al}$ as a cathode). The most noticeable difference between the properties of that organic cell and the best cell in the present work is the FF. In fact, if the cell D4 had the same FF (0.628) the PCE would increase significantly. It is necessary realized more research in order to had best FF and PCE.

\section{Conclusions}

$\mathrm{TiO}_{2}$ and $\mathrm{MoO}_{3}$ showed the optical, electrical and structural properties to be used as transport layers in the structure proposed. Also, work function and thermal stability of FTO had a good matching with the $\mathrm{TiO}_{2}$ conduction band and annealing at $550{ }^{\circ} \mathrm{C}$. In addition, the thickness of the ETL, as well as the thickness, temperature and annealing time of the active layer, played an important role in increasing the efficiency of the built cells. According to experiments, a relatively high thickness of ETL permits increase the PCE, similar to increasing the thickness in the active layer. Also, increasing the time of active layer's annealing can increase the PCE, but continuing to increase said time causes a decrease in efficiency. In fact, in this work with the experiments made, a thickness of $70 \mathrm{~nm}$ is recommended for the ETL and a thickness of $250 \mathrm{~nm}$ for the active layer, which must also be heat treated at $100^{\circ} \mathrm{C}$ for a time close to 10 minutes. Furthermore, the device showed the lowest PCE of $0.44 \%$ without transport layers and the PCE was enhanced to $3.3 \%$ when the transport layers, with the best 
conditions, were incorporated into the device. However, FF must be improved to achieve greater efficiencies.

\section{Acknowledgments}

Authors acknowledge the FONDEC21-UAQ for the financial support fellowship from Fondo Sectorial CONACYTSecretaría de Energía-Sustentabilidad Energética 2018-2019.

\section{References}

1. Hösel M, Angmo D, Krebs F. Organic solar cells (OSCs). In: Ostroverkhova $\mathrm{O}$, editor. Handbook of organic materials for electronic and photonic devices. Cambridge: Woodhead Publishing; 2013. p. 473-507.

2. Yuksel SA, Ongul F, Bozar S, Varal NM, Kus M, Cakmak $\mathrm{G}$, et al. Improvement of photovoltaic performance and stability of AnE-PV:PCBM based organic solar cells using solution processed inverted geometry. Vacuum. 2015;122:161-7. http:// dx.doi.org/10.1016/j.vacuum.2015.09.027.

3. Huang Z, Zhou R, Lv M, Zhang H, Yang C, Shi Y, et al. Constructing high efficiency non-fullerene all-small-molecule ternary organic solar cells by employing structurally similar acceptors. Mater Chem Front. 2021;5(3):1405-9. http://dx.doi. org/10.1039/D0QM00814A.

4. Ghosekar IC, Patil GC. Review on performance analysis of P3HT: $\{$ PCBM $\}$-based bulk heterojunction organic solar cells. Semicond Sci Technol. 2021;36(4):45005. http://dx.doi. org/10.1088/1361-6641/abe21b.

5. Chander N, Jayaraman E, Rawat M, Bagui A, Iyer SSK. Stability and reliability of PTB7:PC71BM and PTB7:PC61BM inverted organic solar cells: a comparative study. IEEE J. Photovoltaics. 2018. http://dx.doi.org/10.1109/JPHOTOV.2018.2874952.

6. Holliday S, Ashraf RS, Wadsworth A, Baran D, Yousaf SA, Nielsen CB, et al. High-efficiency and air-stable P3HT-based polymer solar cells with a new non-fullerene acceptor. Nat Commun. 2016;7:1-11. http://dx.doi.org/10.1038/ncomms11585.

7. Kada EZO, Jouad Z, Benchouk K, Kouskoussa B, Cattin L, Makha M, et al. Effect of MoO3 in the cathode buffer layer on the behaviour of layered organic solar cells. Indian J Pure Appl Phy. 2014;52:829.

8. Lin WK, Su SH, Yeh MC, Chen CY, Yokoyama M. Enhancing efficiency of perovskite solar cells using a thin buffer layer. Vacuum. 2017;140:82-8. http://dx.doi.org/10.1016/j. vacuum.2016.12.037.

9. Kadhum M, Kadem B, Hassan AK. Rutile TiO2 films as electron transport layer in inverted organic solar cell. J Mater Sci Mater Electron. 2018;29. http://dx.doi.org/10.1007/s10854-018-87032.

10. Choi JK, Jin ML, An CJ, Kim DW, Jung H-T. High-Performance of PEDOT/PSS free organic solar cells on an air-plasma-treated ITO substrate. ACS Appl Mater Interfaces. 2014;6(14):1104753. http://dx.doi.org/10.1021/am4049964.

11. Lattante S, Ennio F. Electron and hole transport layers: their use in inverted bulk heterojunction polymer solar cells. Electronics. 2014;3(1):132-64. http://dx.doi.org/10.3390/electronics3010132.

12. Bechara R, Petersena J, Gernigon V, Lévêque P, Heiser T, Toniazzo V, et al. PEDOT:PSS-free organic solar cells using tetrasulfonic copper phthalocyanine as buffer layer. Sol Energy Mater Sol Cells. 2012;98:482-5. http://dx.doi.org/10.1016/j. solmat.2011.11.005.

13. Weickert J, Sun H, Palumbiny C, Hesse HC, Schmidt-mende L. Solar energy materials \& solar cells spray-deposited PEDOT : PSS for inverted organic solar cells. Sol Energy Mater Sol Cells. 2010;94(12):2371-4. http://dx.doi.org/10.1016/j. solmat.2010.08.018.
14. Xu B, Gopalan S, Gopalan A, Muthuchamy N, Lee K, Lee $\mathrm{J}$, et al. Functional solid additive modified PEDOT:PSS as an anode buffer layer for enhanced photovoltaic performance and stability in polymer solar cells. Sci Rep. 2017;7:45079. http:// dx.doi.org/10.1038/srep45079.

15. Hu H, Deng C, Xu J, Zhang K, Sun M. Metastable h-MoO3 and stable $\alpha-\mathrm{MoO} 3$ microstructures: controllable synthesis, growth mechanism and their enhanced photocatalytic activity. J Exp Nanosci. 2015;10(17):1336-46. http://dx.doi.org/10.108 0/17458080.2015.1012654.

16. Al-hashimi MK, Kadem BY, Hassan AK. Rutile TiO2 films as electron transport layer in inverted organic solar cell. J Mater Sci Mater Electron. 2018;29(9):7152-60. http://dx.doi. org/10.1007/s10854-018-8703-2.

17. Hanaor DAH, Sorrell CC. Review of the anatase to rutile phase transformation. J Mater Sci. 2011;46:855-74. http://dx.doi. org/10.1007/s10853-010-5113-0.

18. Liu H, Avrutin V, Izyumskaya N, Özgür Ü, Morkoç H. Transparent conducting oxides for electrode applications in light emitting and absorbing devices. Superlattices Microstruct. 2010;48(5):45884. http://dx.doi.org/10.1016/j.spmi.2010.08.011.

19. Koirala M, Pradhan Joshi L. Structural and optical properties of fluorine doped tin oxide thin film deposited by home built spray pyrolysis unit. Himal Phys. 2017;6:58. http://dx.doi. org/10.3126/hj.v6i0.18361.

20. Elamurugu E, Ramamurthi K. Optoelectronic properties of spray deposited $\mathrm{SnO} 2 \mathrm{~F}$ thin films for window materials in solar cells. J Optoelectron Adv Mater. 2003;5(1):45-54.

21. Chen F, Chien S, Cious G. Highly sensitive, low-voltage, organic photomultiple photodetectors exhibiting broadband response. Appl Phys Lett. 2010;97:103301. http://dx.doi. org/10.1063/1.3488017.

22. Zhang Q, Ma L, Shao M, Huang J, Ding M, Deng X, et al. Anodic oxidation synthesis of one-dimensional tio2 nanostructures for photocatalytic and field emission properties. J Nanomater. 2014;2014:831752. http://dx.doi.org/10.1155/2014/831752.

23. Tiwari R, Sharma MP, Bajpai PK. Raman analysis of Ni doped $\mathrm{ZnO}(\mathrm{Ni}: \mathrm{ZnO})$ thin films by sol - gel spin coating system for device applications. Int J Electr Electron Res. 2015;3(4):27-31.

24. Anefnaf I, Benhaddou N, Aazou S. Optical, Structural and Photoconductivity Properties of Organic Photovoltaic Thin Films Based on Polymer / Fullerene. In: 2016 International Renewable and Sustainable Energy Conference (IRSEC); Piscataway. Piscataway: IEEE; 2016. p. 801-4.

25. Gao J, Berkeley L, Grey JK. Resonance Raman overtones reveal vibrational displacements and dynamics of crystalline and amorphous poly (3-hexylthiophene) chains in fullerene blends crystalline and amorphous poly (3-hexylthiophene) chains in fullerene blends. J Chem Phys. 2014; 139 :044903. http://dx.doi.org/10.1063/1.4815819.

26. Sharma T, Singhal R, Vishnoi R, Lakshmi GBVS, Chand S, Avasthi DK, et al. Ion irradiation induced modifications of P3HT: a donor material for organic photovoltaic devices. Vacuum. 2017;135:73-85. http://dx.doi.org/10.1016/j.vacuum.2016.10.027.

27. Urbano M, Muñoz YO, Fernández YO, Mosquera P, Paez J, Amado RJC. Nanoparticles of TiO2, anatase phase, synthesized by chemical methods. Ing y Desarro. 2011;29:186-201.

28. Chandoul F, Boukhachem A, Hosni F, Moussa H, Fayache MS, Amlouk M, et al. Change of the properties of nanostructured $\mathrm{MoO} 3$ thin films using gamma-ray irradiation. Ceram Int. 2018;44(11):12483-90. http://dx.doi.org/10.1016/j. ceramint.2018.04.040.

29. Stoyanova A, Iordanova R, Mancheva M, Dimitriev Y. Synthesis and structural characterization of $\mathrm{MoO} 3$ phases obtained from molybdic acid by addition of $\mathrm{HNO} 3$ and $\mathrm{H} 2 \mathrm{O} 2$. J Optoelectron Adv Mater. 2009;11:1127-31. 
30. Bumi K, Andounohu T. Particle size analysis of titanium dioxide by atomic force microscopy. J Waste Manag Technol. 2010;13(1):63-71.

31. Ponce-Mosso M, Pérez-González M, García-Tinoco PE, Crotte-Ledesma H, Morales-Luna M, Tomás SA. Enhanced photocatalytic activity of amorphous $\mathrm{MoO} 3$ thin films deposited by rf reactive magnetron sputtering. Catal Today. 2018;349:1508. http://dx.doi.org/10.1016/j.cattod.2018.04.065.

32. Bezrodna T, Puchkovska G, Shymanovska V, Hauser A. X-ray and AFM studies of polydisperse $\mathrm{TiO} 2$ (anatase) particles. J Phys Chem Solids. 2005;66:1057-63. http://dx.doi.org/10.1016/j. jpcs.2005.02.001

33. Hari Krishna K, Hussain O, Guillén C. Photo- and electrochromic properties of activated reactive evaporated $\mathrm{MoO} 3$ thin films grown on flexible substrates. Res Lett Nanotechnol. 2008;2008:217510. http://dx.doi.org/10.1155/2008/217510.

34. Courtier NE, Cave JM, Foster JM, Walker AB, Richardson G. How transport layer properties affect perovskite solar cell performance: insights from a coupled charge transport/ion migration model. Energy Environ Sci. 2019;12(1):396-409. http://dx.doi.org/10.1039/C8EE01576G.

35. Menke SM, Ran NA, Bazan GC, Friend RH. Understanding energy loss in organic solar cells: toward a new efficiency regime. Joule. 2018;2(1):25-35. http://dx.doi.org/10.1016/j. joule.2017.09.020.

36. Dittrich T. Materials concepts for solar cells. 2nd ed. Singapore: Singapore World Scientific; 2018.

37. Gaspar H, Figueira F, Pereira L, Mendes A, Viana J, Bernardo G. Recent developments in the optimization of the bulk heterojunction morphology of polymer: fullerene solar cells. Materials. 2018;11:2560. http://dx.doi.org/10.3390/ma11122560.

38. Li G, Shrotriya V, Huang J, Yao Y, Moriarty T, Emery K. Highefficiency solution processable self-organization of polymer blends. Nat. Publ. Gr. 2005;4:864-8. http://dx.doi.org/10.1038/ nmat 1500

39. Kadem B, Hassan AK, Cranton W. Efficient P3HT:PCBM bulk heterojunction organic solar cells; effect of post deposition thermal treatment. J Mater Sci Mater Electron. 2016;27. http:// dx.doi.org/10.1007/s10854-016-4661-8.

40. Ameen MY, Shamjid P, Abhijith T, Radhakrishnan T, Reddy VS. Stability enhancement of P3HT:PCBM polymer solar cells using thermally evaporated $\mathrm{MoO} 3$ anode buffer layer. Physica B. 2018;530:201-7. http://dx.doi.org/10.1016/j.physb.2017.11.050.

41. Chambon S, Derue L, Lahaye M, Pavageau B, Hirsch L, Wantz G. MoO3 thickness, thermal annealing and solvent annealing effects on inverted and direct polymer photovoltaic solar cells. Materials. 2012;5:2521. http://dx.doi.org/10.3390/ma5122521. 